\title{
SURAT HAK ATAS TANAH
}

\author{
R. Desril* \\ Prodi Hukum Fakultas Hukum \\ *email : r.desrileril@ymail.com
}

\begin{abstract}
Abstrak
Perkembangan pesat yang terjadi dalam pembangunan di Indonesia khususnya Pekanbaru Riau tidak bisa dipisahkan hubungannya dengan tanah, karena tanah jelas menjadi aspek penting dalam pembangunan, dimana seluruh kegiatan pembangunan yang dilakukan memerlukan tanah.Peningkatan pembangunan akan berdampak kepada semakin banyaknya lahan baru yang dibutuhkan, sehingga sertifikat sebagai bentuk legalititas kepemilikan tanah diperlukan sebagai dasar kepemilikan hak.Kurangnya kesadaran masyarakat mengenai pentingnya pendaftaran tanah dalam bentuk sertifikat disebabkan masih sedikitnya penyuluhan yang di berikan kepada masyarakat mengenai sertifikat tanah. Sehingga tidak sedikit berdampak tergusurnya warga dari tanah mereka hanya karena pihak lain memiliki sertifikat yang sah.Penulis menilai perlunya menimbulkan kesadaran hukum masyarakat terhadap pentingnya Surat Hak Atas Tanah. Salah satunya melalui penyuluhan hukum kepada masyarakat.
\end{abstract}

Kata kunci : surat hak atas tanah, kesadaran hukum masyarakat, proses pendaftarannya

\section{PENDAHULUAN}

Tanah merupakan bagian penting dari kehidupan manusia. Bahkan untuk meninggalkan dunia orang masih memerlukan tanah minimal ukuran $2 \mathrm{~m}$ x $1 \mathrm{~m}$. Setiap jengkal tanah di mata hukum keagrariaan harus jelas status hak dan pemegang haknya.Aspek pentinglain diantaranya adalah aspek ekonomi. Perkembangan zaman menyebabkan perubahan fungsi tanah yang dahulu hanya digunakan sebagai lahan pertanian, saat ini berubah menjadi komplek pemukiman warga yang mewah, industri, serta pusat bisnis. Manusia hidup dan berkembang serta melakukan aktivitas di atas tanah sehingga setiap saat manusia berhubungan dengan tanah.

Urgensi tanah bagi kehidupan manusia diapresiasi Pemerintah Republik Indonesia melalui kebijakan nasional pertanahan dengan dikeluarkannya Undang-
Undang Nomor 5 tahun 1960 Tentang Peraturan Dasar PokokPokok Agraria yang juga disingkat UUPA. UUPA merupakan tonggak utama kelahiran ketentuan pertanahan di Indonesia, didalamnya mengatur berbagai macam hak atas tanah. Dari berbagai macam hak atas tanah yang ada, Sertipikat Hak Milik atas tanah adalah hak atas tanah yang terkuat, terpenuh dan turun-menurun yang dapat dipunyai orang atas tanah dan hanyaSertipikat Hak Milik saja yang tidak dibatasi masa berlakunya oleh negara dibanding dengan hak atas tanah yang lain seperti Sertipikat Hak Guna Usaha, Sertipikat Hak Guna Bangunan, Sertipikat Hak Pakai.

UUPA merupakan amanat pelaksanaan Pasal 33 ayat (3) Undang-Undang Dasar Negara Republik Indonesia Tahun 1945 menentukan, bumi air dan kekayaan alam yang terkandung didalamnya dikuasai oleh Negara dan 
dipergunakan sebesar-besarnya kemakmuran rakyat, yang kemudian dalam Pasal 19 UUPA pengaturan pendaftaran tanah dilakasanakan oleh Peraturan Pemerintah No. 24 Tahun 1997tentang Pendaftaran Tanah.

Peraturan Pemerintah No. 24 Tahun 1997 tentang Pendaftaran Tanah mengatur bahwa pendaftaran tanah adalah rangkaian kegiatan yang dilakukan oleh Pemerintah secara terus-menerus, berkesinambungan dan teratur, meliputi pengumpulan, pengolahan, pembukuan dan penyajian serta pemeliharaan data fisik dan data yuridis dalam bentuk peta dan daftar, mengenai bidang-bidang tanah dan satuan-satuan rumah susun, termasuk pemberian surat tanda bukti haknya bagi bidang-bidang tanah yang sudah ada haknya dan hak milik atas satuan rumah susun serta hak-hak tertentu yang membebaninya.

Di Indonesia banyak masyarakat yang mengusai tanah melaui pewarisan secara lisan tanpa bukti hukum yang bisa berakibat konflik dengan pihak lain yang bisa menunjukkan bukti kuat kepemilikan atas tanah tersebut. Hal ini disebabkan kurangnya kesadaran hukum masyarakat serta minimnya pengetahuan masyarakat tentang proses pengurusan Surat hak atas tanah. Oleh karena itu negara dirasa perlu untuk memberikan penekanan akan pentingnya surat hak atas tanah guna memberikan perlindungan dan kepastian hukum serta mengantisipasi terjadinya berbagai masalah kepemilikan tanah yang tidak diinginkan.

Surat hak atas tanah berupa sertifikat merupakan akta otentik, yaitu suatu akta yang di dalam bentuk yang ditentukan oleh undang- undang, dibuat oleh atau di hadapan pegawai-pegawai umum yang berkuasa untuk itudi tempat di mana akta dibuatnya.

Secara yuridis, jual beli sebagai salah satu perbuatan hukum peralihan hak milik telah diatur di dalam Undang-Undang, yaitu Undang-Undang Nomor 5 tahun 1960 tentang Peraturan Dasar PokokPokok Agraria (UUPA). UUPA memberikan kewenangan kepada pemilik tanah untuk memanfaatkan tanah miliknya semaksimal mungkin termasuk di dalamnya melakukan perbuatan hukum peralihan hak atas tanah.Dengan di berikan hak atas tanah tersebut maka orang atau badan hukum sebagai pemilik tanah telah terjalin suatu hubungan hukum. Dengan adanya hubungan hukum dapat di lakukan suatu perbuatan hukum oleh yang mempunyai hak itu terhadap tanah kepada pihak lain umpamanya dapat melakukan perbuatan hukum berupa jual-beli, tukar menukar, hibah, wakaf dan lain sebagainya.

Dalam Pembangunan Nasional Indonesia, pemerintah mempunyai posisi sentral paling depan. Pemerintah juga mempunyai tugas untuk menciptakan efektifitas dan efisiensi dalam usaha mencapai tujuan negara dan tujuan nasional. Sejalan dengan itu Presiden mengeluarkan Keputusan Nomor 34 Tahun 2003 tentang kebijakan nasional di bidang pertanahan. Bahwa seluruh wilayah Indonesia adalah kesatuan tanah air dari seluruh rakyat Indonesia, yang bersatu sebagai bangsa Indonesia, dalam kerangka Negara Kesatuan Republik Indonesia.Dalam rangka mewujudkan konsepsi, kebijakan dan sistem pertanahan nasional yang utuh 
dan terpadu, serta pelaksanaan Tap MPR Nomor IX/MPR/2001 tentang pembaruan Agraria dan Pengelolaan Sumber Daya Alam.

Sehingga perluadanyapengkajian mengenai prosedur yang diterapkan Badan Pertanahan Nasional agar kualitas pelayanan kedepan bisa optimal secara cepat,tepat,baik dan akurat. Dan kemudian mencari tahu permasalahan permasalahan seperti faktor yang menjadi penghambat yaitu disiplin pegawai,tingkat pelayanan kurang, pembuatan suratsurat keterangan dan lainnya terlambat

dantidaktepatwaktusertasarana

pendukung dalam menunjang kegiatan dilapangan kurangserta prosedur atau mekanisme yang harus dilalui oleh para calon pemegang sertifikat tanah dari kantor BPN yang dianggap sulit dan berbelit-belit.

\section{METODE PENGABDIAN}

\section{Permasalahan}

Dari Latar Belakang tersebut di atas maka penulis rumuskan permasalahannnya yaitu terkait bagaimana membangun kesadaran hukum masyarakat terhadap pentingnya Surat Hak Atas Tanah ? dan Bagaimana proses pengurusan Surat Hak Atas Tanah di Badan Pertanahan Nasional?

\section{HASIL DAN PEMBAHASAN}

1. Surat Hak Atas Tanah

Dalam UUPA tidak pernah disebut sertifikat tanah, namun seperti yang dijumpai dalam Pasal 19 Ayat (2) huruf $\mathrm{c}$ ada disebutkan "surat tanda bukti hak". Dalam pengertian sehari-hari surat tanda bukti hak ini sudah sering ditafsirkan sebagai sertifikat tanah. Dan penulispun di sini membuat pengertian yang sama bahwa surat tanda bukti hak adalah sertipikat.

Sertipikat sangat penting bagi kepemilikan hak atas tanah guna menjamin kepastian hukum terhadap pemegang hak atas tanah tersebut. Hal ini disebutkan dalam pasal 19 Undang-undang Pokok Agraria yang mengatur:

1. Untuk menjamin kepastian hukum oleh pemerintah diadakan pendaftaran tanah di seluruh wilayah Republik Indonesia menurut ketentuanketentuan yang diatur dalam peraturan pemerintah.

2. Pendaftaran tanah dalam ayat 1 pasal ini meliputi :

a. Pengukuran, perpetaan, dan pembukuan tanah.

b. Pendaftaran hak-hak atas tanah dan peralihan hak-hak tersebut.

c. Pemberian surat-surat tanda bukti hak, yang berlaku sebagai alat bukti yang kuat.

Salah satu tujuan pendaftaran tanah sebagaimana yang ditetapkan dalam pasal 3 Peraturan Pemerintahan Nomor 24 Tahun 1997 Tentang Pendaftaran Tanah adalah untuk memberikan kepastian hukum dan perlindungan hukum kepada pemegang hak atas suatu bidang tanah,satuan rumah susun dan hakhak lain yang terdaftar agar dengan mudah dapat membuktikan dirinya sebagai pemegang hak yang bersangkutan.Untuk memberikan kepastian hukum dan perlindungan hukum, kepada pemegang hak yang bersangkutan diberikan sertifikat hak atas tanah.

Meski sudah mendapat pengakuan dalam UUPA, sertifikat belum menjamin kepastian hukum pemiliknya karena dalam peraturannya sendiri memberi 
peluang dimana sepanjang ada pihak lain yang merasa memiliki tanah dapat menggugat pihak yang namanya tercantum dalam sertifikat secara keperdataan ke Peradilan Umum, atau menggugat Kepala BPN/Kepala Kantor Pertanahan yang bersangkutan ke Pengadilan Tata Usaha Negarta, atau gugatan yang menyangkut teknis administrasi penerbitannya.

Sertifikat sebagai tanda bukti hak yang bersifat mutlak apabila memenuhi unsur-unsur secara kumulatif yaitu :

1. Sertifikat diterbitkan secara sah atas nama orang atau badan hukum

2. Tanah diperoleh dengan itikad baik

3. Tanah di kuasai secara nyata

4. Dalam waktu 5 (lima) tahun sejak diterbitkan sertifikat itu tidak ada yangmengajukan keberatan secara tertulis kepada pemegang sertifikat dan KepalaKantor Pertanahan Kabupaten/Kota setempat ataupun mengajukangugatan tidak pengadilan mengenai penguasaan tanah atau penerbit sertifikat.

Menurut Boedi Harsono dalam bukunya Hukum Agraria Indonesia, sertipikat hak atas tanah terdiri atas salinan buku tanah dan surat ukur yang dijilid menjadi satu dalam sampul dokumen. Sehubungan dengan hal tersebut diatas dapat diketahui bahwa sertipikat merupakan surat tanda bukti hak yang kuat mengenai data fisik dan data yuridis termuat di dalamnya, sehingga data fisik dan data yuridis tersebut sesuai dengan data yang ada dalam surat ukur dan buku tanah yang bersangkutan.

Sertipikat hak atas tanah berfungsi sebagai alat pembuktian yang kuat serta memberikan rasa aman dan tentram bagi pemiliknya, segala sesuatu akan mudah diketahui yang sifatnya pasti, bahkan dapat di pertanggung jawabkan secara hukum.

Pemilikan hak atas tanah oleh seseorang atau badan hukum harus dibuktikan.Pembuktian kepemilikan hak atas tanah di lakukan atau ditunjukan dengan beragai macam alat bukti. Namun pembuktian yang terkuat adalah melalui sertifikat tanah yang merupakan tanda bukti pembuktian terkuat bagi kepemilikan hak atas tanah disebutkan dalam Pasal 19 ayat (2) huruf c UUPA , yaitu sertifikat sebagai alat pembuktian yang kuat, yaitu data fisik dan data yuridis yang dimuat dalam sertifikat dianggap benar sepanjang tidak dapat di buktikan sebaliknya oleh alat bukti yang lain yang dapat berupa sertifikat atau selain sertifikat. Untuk memperoleh sertifikat tanah maka sudah pasti terhadap tanah tersebut harus di daftarkan ke Kantor Pertanahan

Dengan demikian sertipikat hak atas tanah yang ditegaskan oleh peraturan perundang-undangan tersebut sebagai surat tanda bukti hak, jadi sudah dijamin mempunyai kekuatan hukum sebagai alat pembuktian yang kuat mengenai pemilikan terhadap hak atas tanah. Walaupun fungsi utama sertipikat hak atas tanah adalah sebagai alat bukti, tetapi dalam kenyataannya sertipikat bukanlah merupakan satusatunya alat bukti kepemilikan hak atas tanah. 
Dalam hal pembuktian dapat dilihat pada Pasal 23 Peraturan Pemerintah Nomor 24 Tahun 1997 yang mengatur tentang pembuktian kepemilikan hak atas tanah menyatakan bahwa dalam rangka mempeoleh kebenaran data yuridis bagi hak-hak yang baru dan untuk keperluan pendaftaran hak maka pembuktiannya di lakukan dengan :

1. Penetapan pemberian hak dari pejabat yang berwenang memberikan hak yang bersangkutan menurut ketentuan yang berlaku apabila pemberian hak tersebutberasal dari tanah negara atau tanah hak pengelolaan. Penetapan pejabat yangberwenang mengenai pemberian hak atas tanah negara dapat di keluarkansecara individu, kolektif maupun secara umum.

2. Asli akta PPAT yang memuat pemberian hak tersebut oleh pemegang HakMilik kepada penerima hak yang bersangkutan mengenai Hak GunaBangunan atau Hak Pakai atas tanah Hak Milik. Pemberian Hak GunaBangunan atau Hak Pakai atas tanah Hak Milik di samping di atur dalamPeraturan Pemerintah Nomor 40 tahun 1996, juga di atur dalam PeraturanMentri Negara Agraria/Kepala BPN Nomor 9 tahun 1999.

Dengan terdaftarnya tanah, sebenarnya tidak semata-mata akan terwujud jaminan keamanan akan kepemilikannya dalam menuju kepastian hukum, bahkan seseorang pemilik akan mendapatkan kesempurnaan dari haknya, karena :

1. Adanya rasa aman dalam memiliki hak atas tanah (security)
2. Mengerti dengan baik apa dan bagaimana yang diharapkan dari pendaftaran tersebut (simplity)

3. Adanya jaminan ketelitian dalam system yang dilakukan (accuracy)

4. Mudah dilaksanakan (expedition)

5. Dengan biaya yang bisa dijangkau oleh semua orang yang hendak mendaftar tanah (cheapness), dan daya jangkau ke depan dapat diwujudkan terutama atas harga tanah itu kelak (suitable).

Sertipikat adalah surat tanda bukti hak, oleh karena itu telah kelihatan berfungsinya, bahwa sertifikat itu berguna sebagai "alat bukti". Alat bukti yang menyatakan tanah ini telah diadministrasi oleh Negara. Dengan dilakukan administrasinya lalu diberikan buktinya kepada orang yang mengadministrasi tersebut. Bukti atau sertipikat adalah milik seseorang sesuai dengan yang tertera dalam tulisan di dalam sertipikat tersebut.

Sehingga sebagaimana yang telah diuraikan di atas bagi si pemilik tanah, sertipikat tersebut sungguh merupakan pegangan yang kuat dalam hal pembuktian hak miliknya, sebab dikeluarkan oleh instansi yang sah dan berwenang secara hukum yaitu Badan Pertanahan Nasional.Hukum melindungi pemegang sertipikat tersebut dan lebih kokoh bila pemegang itu adalah namanya yang ada dalam sertipikat. Sehingga bila yang memegang sertipikat itu belum namanya maka perlu dilakukan balik namanya kepada yang memegang sehingga terhindar lagi dari gangguan pihak lain.

Dengan demikian surat tanda bukti atau sertipikat tanah itu dapat 
berfungi menciptakan tertib hukum pertanahan serta membatu mengaktifkan kegiatan perekonomian rakyat. Adapun bentuk-bentuk sertipikat hak atas tanah dapat dikelompokkan sebagai berikut Hak Guna Bangunan (HGB) Hak Guna Usaha (HGU) Hak Pakai yang masing-masing memiliki perbedaan peruntukan dan proses administrasi kelengkapan syarat untuk pengurusan surat haknya.

2. Kesadaran Hukum Masayarakat

Kesadaran hukum masyarakat sebenarnya menyangkut faktorfaktor apakah suatu ketentuan hukum tertentu diketahui, dimengerti, ditaati dan dihargai. Apabila masyarakat hanya mengetahui adanya suatu ketentuan hukum, maka taraf kesadaran hukumnya masih rendah dari pada apabila mereka memahaminya, dan seterusnya.

Kesadaran hukum juga dikemukakan oleh Ewick dan Silbey yaitu mengacu ke cara-cara dimana orang-orang memahami hukum dan institusi-institusi hukum, yaitu pemahaman-pemahaman yang memberikan makna kepada pengalaman dan tindakan orangorang.

Menurut Soerjono Soekanto terdapat empat indikator kesadaran hukum yang masing-masing merupakan suatu tahapan bagi tahapan berikutnya, yaitu: (1) Pengetahuan hukum adalah Artinya seseorang mengetahui bahwa perilaku-perilaku hukum tersebut diatur oleh hukum. Maksudnya bahwa hukum disini adalah hukum tertulis atau hukum tidak tertulis. Pengetahuan hukum menyangkutperilaku yang dilarang oleh hukum atau perilaku yang diperbolehkan oleh hukum (2) Pemahaman hukum artinya seorang warga masyarakat mempunyai pengetahuan mengenai aturan-aturan tertentu, terutama dalam segi isinya, pemahaman hukum berkaitan dengan apakah seseorang mengerti tentang isi hukum yang berlaku (3) Sikap hukum Artinya seseorang mempunyai kecendrungan untuk mengadakan penilaian terhadap hukum, dan (4) Pola perilaku hukum Artinya dimana seseorang berperilaku sesuai dengan hukum.

Menurut Yahya Harahapbahwa faktor-faktor yang mempengaruhi kesadaran hukum yaitu: (1) Faktor kecerdasan masyarakat, (2) faktor tingkat kehidupan sosial ekonomis. (3) faktor latar belakang budaya yang masih diliputi sikap paternalism, dan (4) faktor penyuluhan hukum yang efektif.

Dari kumpulan pendapat ahli hukum tentang kesadaran hukum masyarakat diatas, ada beberapa poin penting yang bisa dipahami tentang kesadaran hukum tersebut yaitu:

1. Mengetahui, yaitu hal pertama yang harus sampai kepada masyarakat adalah pengetahuan tentang apa-apa saja bentuk surat hak atas kepemilikan tanah sebagaimana ketentuan Perundang undangan yang berlaku.

2. Memahami, yaitu terhadap pengetahuan tentang bentuk surat hak atas kepemilikan tanah sebagaimana huruf a di atas selanjutnya masyarakat memahami konsekuwensi hukum dengan memiliki dan atau tidak memiliki surat ha katas kepemilikan tanah tersebut. 
ISSN : 2550-0198

3. Kesadaran hukum, yaitu timbulnya kesadaran pada diri masing-masing masyarakat begitu pentingnya memiliki surathakatas kepemilikan tanah dari berbagai aspek, baik aspek hukum maupun ekonomisnya.

4. Budaya hukum masyarakat, yaitu seluruh masyarakat memiliki pandangan yang sama tentang surat hak atas kepemilikan tanah konsekuwensi hukum memiliki dan atau tidak memiliki surat hak atas kepemilikan tanah tersebut.

Terhadap penjelasan tentang kesadaran hukum masyarakat di atas langkah yang dilakukan adalah penyuluhan hukum kepada masyarakat tentang surat ha katas tanah,

3. Proses Pengurusan Surat Hak Atas Tanah

Dalam pengurusan surathakatas tanah anggapan masyarakat sistem birokrasi yang kurang baik di BPN sehingga berdampak secara langsung terhadap rendahnya keinginan masyarakat dalam mengurus administrasi, terutama pengurusan surat hak atas tanah.

Pensertipikatan tanah secara massal melalui PRONA merupakan salah satu kegiatan pembangunan pertanahan yang mendapat tanggapan positif dari masyarakat. Selama ini pelaksanaan kegiatan pendaftaran tanah dalam 5 dekade, yang dimulai pada tahun 1961 baru mampu melaksanakan pendaftaran tanah sebanyak \pm 34 juta bidang dari \pm 85 juta bidang. Pasal 19 Undangundang Nomor 5 Tahun 1960 tentang Peraturan Dasar Pokokpokok Agraria (UUPA) menetapkan bahwa untuk menjamin kepastian hukum oleh Pemerintah diadakan pendaftaran tanah di seluruh wilayah Republik Indonesia. Sehubungan dengan hal tersebut Badan Pertanahan Nasional Republik Indonesia (BPN-RI) yang berdasarkan Peraturan Presiden Nomor 10 Tahun 2006 tentang Badan Pertanahan Nasional, ditugaskan untuk melaksanakan urusan pemerintahan di bidang pertanahan, antara lain melanjutkan penyelenggaraan percepatan pendaftaran tanah sesuai dengan amanat Pasal 19 tersebut, terutama bagi masyarakat golongan ekonomi lemah sampai menengah melalui kegiatan PRONA yang sudah dilaksanakan sejak tahun 1981.

Percepatan pendaftaran tanah diselenggarakan hendaknya memperhatikan prinsip bahwa tanah secara nyata dapat meningkatkan kesejahteraan masyarakat, berperan secara jelas untuk terciptanya tatanan kehidupan bersama yang lebih berkeadilan, menjamin keberlanjutan kehidupan masyarakat, berbangsa dan bernegara untuk meminimalkan perkara, masalah, sengketa dan konflik pertanahan. Selain daripada itu percepatan pendaftaran tanah juga merupakan pelaksanaan dari 11 Agenda BPN-RI, khususnya untuk meningkatkan pelayanan pelaksanaan pendaftaran tanah secara menyeluruh, dan penguatan hak-hak rakyat atas tanah.

Adapun dasar hukum yang dapat dipedomani terkait dengan hak atas tanah adalah sebagai berikut:

1. UU No. 5 Tahun 1960 tentang Peraturan Dasar Pokok-Pokok Agraria.

2. Peraturan Pemerintah Nomor 40 Tahun 1996 tentang Hak Guna Usaha, Hak Guna Bangunan dan Hak Pakai atas Tanah. 
3. Peraturan Pemerintah Nomor 24 Tahun 1997 tentang Pendaftaran Tanah.

4. Peraturan Pemerintah Nomor 13 Tahun 2010 tentang Tarif Atas Jenis Penerimaan Negara Bukan Pajak Yang Berlaku Pada Badan Pertanahan Nasional.

5. Peraturan Presiden Nomor 10 Tahun 2006 tentang Badan Pertanahan Nasional.

6. Peraturan Menteri Negara Agraria/Kepala Badan Pertanahan Nasional No. 3 tahun 1997 tentang Ketentuan Pelaksanaan Peraturan Pemerintah Nomor 24 tahun 1997, tentang Pendaftaran Tanah.

7. Peraturan Menteri Negara Agraria/Kepala Badan Pertanahan Nasional No. 3 tahun 1999 tentang Pelimpahan Kewenangan Pemberian dan Pembatalan Keputusan Pemberian Hak Atas Tanah Negara.

8. Peraturan Menteri Negara Agraria/Kepala Badan Pertanahan Nasional No. 9 tahun 1999 tentang Tata Cara Pemberian dan Pembatalan Hak Atas Tanah Negara dan Hak Pengelolaan.

9. Peraturan Kepala Badan Pertanahan Nasional Republik Indonesia Nomor 3 Tahun 2006 tentang Organisasi dan Tata Kerja Badan Pertanahan Nasional Republik Indonesia.

10. Peraturan Kepala Badan Pertanahan Nasional Republik Indonesia Nomor 4 Tahun 2006 tentang Organisasi dan Tata Kerja Kantor Wilayah Badan Pertanahan Nasional Provinsi dan Kantor Pertanahan Kabupaten/Kota Adapun tujuan penyelenggaraan $\backslash \mathrm{ONA}$ memberikan pelayanan pendaftaran tanah pertama kali dengan proses yang sederhana, mudah, cepat, dan murah dalam rangka percepatan pendaftaran tanah.Tahap Pelaksanaan Kegiatan PRONA tersebut adalah sebagai berikut:

1. Usulan lokasi desa yang disesuaikan dengan kriteria

2. Penetapan lokasi desa sebagai lokasi PRONA

3. Penyuluhan oleh Tim Penyuluh Kantor Pertanahan

4. Pembentukan Satuan Tugas Pengumpul Data Yuridis

5. Pendataan oleh Satgas Pengumpul Data Yuridis untuk kelengkapan berkas permohonan dan penyerahan Surat Tanda Terima Dokumen (STTD)

6. Pemasangan Titik Dasar Teknis orde IV dan pengukuran kerangka dasar teknis

7. Penetapan batas bidang tanah oleh pemilik tanah dengan persetujuan tetangga yang berbatasan di setiap sudut bidang tanah dan dilaksanakan pemasangan tanda batasnya.

8. Pengukuran bidang - bidang tanah berdasarkan tanda batas yang telah ditetapkan dan terpasang.

9. Sidang Panitia untuk meneliti subyek dan obyek tanah yang dimohon dengan memperhatikan persyaratan yang dilampirkan

10. Pembuktian hak melalui PENGUMUMAN yang diumumkan selama 2 (dua) bulan, guna memberikan kesempatan para pihak untuk mengajukan sanggahan / keberatan (Untuk Tanah Milik Adat)

11. Pengesahan atas pengumuman (Untuk Tanah Milik Adat) 
ISSN : 2550-0198

12. Pembukuan hak dan proses penerbitan sertipikat hak atas tanah

13. Penyerahan sertipikat hak atas tanah di setiap Desa, peserta membawa KTP asli atau surat kuasa bila dikuasakan

Selanjutnya persyaratan yang harus dipenuhi pesertapemilik tanah tersebut dapat dikelompokkan sebagai berikut:

1. Sebelum Tahun 1997 yaitu:

a. Surat Permohonan

b. Surat Pernyataan penguasaan fisik sistimatis bermeterai Rp. 6.000 ,

c. Identitas pemohon (KTP) yang dilegalisir oleh yang berwenang

d. Surat Kuasa bermeterai Rp. 6.000,-bila dikuasakan kepada pihak lain

e. Surat perwalian bila masih di bawah umur bermeterai Rp. 6.000,-- diketahui Kades

f. Salinan Letter D / C yang dilegalisir oleh yang berwenang

g. Bukti Perolehan tanahnya (segel jual beli, segel hibah, surat keterangan warisan dll).

h. Foto copy SPPT dilegalisir oleh yang berwenang.

i. Berita Acara kesaksian diketahui 2 orang saksi

j. Surat pernyataan lain yang diperlukan bermeterai Rp. 6.000,--

k. Memasang patok tanda batas. Permanen (menurut syarat sebagaimana PMNA/Ka BPN No. 3/1997)

2. Pemilikan Tanah sesudah Tahun 1997 yaitu:

a. Jual Beli / Hibah

b. Surat Permohonan c. Surat Pernyataan penguasaan fisik sistimatis bermeterai Rp. 6.000 ,-

d. Foto copy KTP para pihak dilegalisir oleh yang berwenang

e. Foto copy SPPT dilegalisir oleh yang berwenang.

f. Akta jual beli / hibah meterai 2 buah Rp. 12.000,-

g. Salinan Letter C yang dilegalisir oleh yang berwenang

h. Bukti SSB BPHTB

i. Bukti SSP PPh kalau kena pajak $\mathrm{PPh}$

j. Sketsa pemecahan bidang tanah

k. Surat pernyataan pemilikan tanah pertanian bermetersi Rp.6.000,-

1. Memasang patok tanda batas. Permanen (menurut syarat sebagaimana PMNA/Ka BPN No. 3/1997)

3. Pemilikan Tanah Berdasar Warisan yaitu:

a. Foto copy KTP para ahli waris dilegalisir oleh yang berwenang

b. Surat Pernyataan penguasaan fisik sistimatis bermeterai $\mathrm{Rp}$. 6.000 ,-

c. Surat kematian

d. Surat keterangan Warisan bermetari Rp. 6.000,-

e. Surat Perwalian / surat pengampuan

f. Salinan Letter C yang dilegalisir oleh yang berwenang

g. Foto copy SPPT dilegalisir oleh yang berwenang.

h. Surat pernyataan lain bermeterai Rp. 6.000,-

i. Memasang patok tanda batas. Permanen (menurut syarat 
sebagaimana PMNA/Ka BPN No. 3/1997)

4. Warisan dan pembagian milik bersama yaitu

a. Foto copy KTP para ahli waris dilegalisir oleh yang berwenang

b. Surat Pernyataan penguasaan fisik sistimatis bermeterai $\mathrm{Rp}$. 6.000,-

c. Surat kematian

d. Surat keterangan Warisan bermetari Rp. 6.000,-

e. Foto copy SPPT dilegalisir oleh yang oleh yang berwenang

f. Salinan Letter C yang dilegalisir oleh yang berwenang

g. Akta Pembagian Hak bersama (APHB) materai 2 buah $\mathrm{Rp}$. 12.000,-

h. Bukti SSB BPHTB

i. Surat pernyataan lain bermeterai Rp. 6.000,--

j. Memasang patok tanda batas. Permanen (menurut syarat sebagaimana PMNA/Ka BPN No. 3/1997)

Seiring dilaksanakannya reformasi agraria yang salah satu wujudnya memberikan kemudahan dalam proses sertipikasi tanah. Pemerintah melalui Badan Pertanahan Nasional bahkan telah melakukan jemput bola untuk mempermudah proses sertipikasi ini dengan program yang diberi nama Layanan Rakyat untuk Sertipikasi Tanah ( Larasita ). Layanan dengan mendatangi masyarakat dan menggunakan sistem online. Sebagai sebuah kebijakan inovatif yang bertujuan memberikan layanan administratif memfasilitasi masyarakat dalam melaksanakan legalisasi aset tanahnya. Serta meringankan masyarakat dalam pengeluaran biaya untuk mendatangi loket di Kantor Badan Pertanahan Nasional yang jaraknya cukup jauh dari tempat tinggal mereka.

Masyarakat yang mendatangi loket juga akan mendapatkan pelayanan dengan sistem komputerisasi yang lebih transparan dan terbangunnya database pertanahan yang lebih baik. Dengan melengkapi persyaratan mengisi formulir, fotocopy identitas, bukti perolehan hak atas tanah, dan syarat administrasi lainnya. Waktu yang dibutuhkan dalam proses pengurusan sertipikat hak milik sebagai berikut :

1. 38 hari untuk tanah pertanian yang luasnya tidak lebih dari 2 Ha dan tanah non pertanian yang luasnya tidak lebih dari 2000 $\mathrm{m} 2$.

2. 57 hari untuk tanah pertanian yang luasnya lebih dari $2 \mathrm{Ha}$ dan tanah non pertanian yang luasnya lebih dari $2000 \mathrm{~m} 2$ $5000 \mathrm{~m} 2$.

3. 97 hari untuk tanah non pertanian yang luasnya lebih dari $5000 \mathrm{~m} 2$.

\section{SIMPULAN}

Dengan diterbitkan sertifikat dalam kegiatan pendaftaran dimaksudkan agar pemegang hak dapat dengan mudah untuk membuktikan haknya.Oleh karena itu sertifikat merupakan suatu alat bukti yang kuat sebagaimana yang dimaksud pada Pasal 19 UUPA.Sertifikat diterbitkan untuk kepentingan pembuktian pemegang hak yang bersangkutan sesuai dengan data fisik dan data yuridis yang telah didaftarkan dalam buku tanah. Dengan data fisik dan data 
ISSN : 2550-0198

yuridis yang tercantum didalam sertifikat harus sesuai dengan data yang tercantum didalam buku tanah dan surat ukur yang bersangkutan. Dengan diterbitkannya sertifikat hak atas tanah maka kepada pemiliknya di berikan kepastian hukum dan perlindungan hukum untuk mencegah adanya sengketa gugatan hukum yang terjadi di kemudian hari akibat dari adanya pihak yang merasa dirugikan akibat terbitnya suatu sertifikat tanah.

\section{DAFTAR PUSTAKA}

[1] Achmad Ali. 2009.Menguak Teori Hukum (Legal Theory) Dan Teori Peradilan (Judicial Prudence): $\quad$ Termaksud Interpretasi Undang-Undang (Legisprudence). Jakarta. Kencana.

[2] Harsono, Boedi. 2008. Hukum Agraria Indonesia, Himpunan Peraturan-Peraturan Hukum Tanah. Jakarta: Penerbit Jambatan

[3] Mudjiono. 1992. Hukum Agraria. Yogyakarta: Penerbit Liberty

[4] Nae, Fandri Entiman. 2013. Kepastian Hukum Terhadap Hak Milik Atas Tanah yang Sudah Bersertipikat. Jurnal Lex Privatum

[5] Petrus R. G. Sinaga. 2014. Sertifikat Hak Atas Tanah dan Implikasi terhadap kepastian kepemilikan tanah. Jurnal Lex et Societatis

[6] Soerjono Soekanto.2006. Pokok-Pokok Sosiologi Hukum. Jakarta: Raja Grafindo Persada.

[7] Tahir, Heri. 2010.Proses Hukum Yang Adil Dalam System Peradilan Pidana Di
Indonesia.Yogyakarta. Laksbang Pressindo.

[8] Zainuddin Ali. 2005. Sosiologi hukum. Jakarta. Sinar Grafika.

[9] www.bpn.go.id/Layananpublik/program/larasita. diakses 15 maret 2017 